\title{
The Role of MicroRNAs in the Cardiac Response to Exercise
}

\author{
Xiaojun Liu, Colin Platt, and Anthony Rosenzweig \\ Cardiology Division, Massachusetts General Hospital and Harvard Medical School, Boston, \\ Massachusetts 02115 \\ Correspondence: rosenzwe@helix.mgh.harvard.edu
}

\begin{abstract}
Noncoding microRNAs (miRNAs) have emerged as central regulators of cardiac biology, modulating cardiac development and the response to pathological stress in disease. Although less well developed, emerging evidence suggests miRNAs are likely also important in the heart's response to the physiological stress of exercise. Given the well-recognized cardiovascular benefits of exercise, elucidating the contribution of miRNAs to this response has the potential not only to reveal novel aspects of cardiovascular biology but also to identify new targets for therapeutic intervention that may complement those discovered through studies of diseased hearts. Here, we first provide an overview of the cardiovascular effects of exercise as well as some of the major protein signaling mechanisms contributing to these effects. We then review the evidence that both cardiac and circulating miRNAs are dynamically regulated by exercise and regulate these mechanisms and phenotypes.
\end{abstract}

\section{THE GROWING BURDEN OF CARDIOVASCULAR DISEASE}

t is ironic that, despite enormous progress in our understanding and ability to treat many cardiovascular diseases, the burden of these conditions in both human and financial terms is increasing and expected to continue to do so. There are likely three principle drivers of this disturbing trend. First, in some ways, it reflects our success at managing acute cardiovascular conditions such as myocardial infarction (MI) and hypertensive crises. As the mortality from these conditions has plummeted over the past half-century (Ford et al. 2007), the increasing number of survivors are at continued risk for late sequelae of their conditions, such as heart failure (HF) and arrhythmia, for which our therapies remain inadequate. Second, as populations age around the world (Christensen et al. 2009), the prevalence of age-related diseases, including cardiovascular disease, increases. Finally, the burgeoning epidemic of metabolic diseases such as obesity and diabetes, substantially increase the risk of most forms of cardiovascular disease, including atherosclerotic vascular disease as well as ischemic injury and HF (Bhupathiraju and $\mathrm{Hu}$ 2016). In the context of this growing unmet clinical need, investigation into the mechanisms responsible for the putative cardiovascular benefits of exercise may complement ongoing studies of the mechanisms of

Editors: Juleen R. Zierath, Michael J. Joyner, and John A. Hawley

Additional Perspectives on The Biology of Exercise available at www.perspectivesinmedicine.org

Copyright (C) 2017 Cold Spring Harbor Laboratory Press; all rights reserved; doi: 10.1101/cshperspect.a029850

Cite this article as Cold Spring Harb Perspect Med 2017;7:a029850 
X. Liu et al.

disease, potentially yielding new insights and targets for intervention.

\section{CLINICAL BENEFITS OF EXERCISE}

The intuitively appealing concept that exercise protects against the development of cardiovascular disease has long been espoused. However, it is worth acknowledging that the large majority of evidence supporting this perspective is observational in nature and thus cannot establish a causal relationship (Wei et al. 2014). Such observational studies are inherently limited by multiple factors, including selection and recall biases, unrecognized confounding, and inaccurate self-reporting of activity. On the other hand, randomized controlled trials, the gold standard of clinical evidence, are also challenged in this context by imperfect adherence to lifestyle interventions, the daunting statistical requirements for adequate power in primary prevention, and the potential inability of patients with cardiovascular disease to exercise adequately in secondary prevention or treatment trials. Nevertheless, the large majority of observational studies show a reduction in cardiovascular disease among those who exercise habitually and, consistent with this, clinical interventional trials also suggest benefits accrued to those with existing cardiovascular disease. Studies of particular note include a recent meta-epidemiological analysis suggesting that the mortality benefit resulting from exercise in patients with coronary disease or early diabetes was comparable to that seen with approved medical therapies (Naci and Ioannidis 2013). One of the largest randomized controlled trials of exercise performed to date is the HFACTION trial, which showed a substantial improvement in HF patients randomized to a structured exercise program in self-reported health status and moderate improvements in several clinical endpoints, including a composite of all-cause mortality and hospitalization, which achieved statistical significance when adjusted for differences in baseline patient characteristics (O'Connor et al. 2009). Thus, although the clinical evidence is imperfect, the consistent message that emerges from observational, epi- demiological, and interventional trials is that exercise has substantive benefits in the prevention and management of cardiovascular disease.

\section{RATIONALE FOR STUDYING EXERCISE}

Although studies of heart disease have yielded important insights, the pathway to therapeutic translation has been challenging, in part because recognizing deleterious changes in disease does not reliably lead to corrective interventions. We know much less about what keeps the heart healthy, and thus delineating the mechanisms by which exercise leads to its cardiovascular benefits may provide a model of the "healthy heart" and in the process lead to novel strategies for preventing or treating heart disease. How likely is it that exercise-related pathways will also mitigate the response to pathological stress and/or established cardiovascular disease? Interestingly, the large majority of pathways identified thus far as functionally important in the cardiac response to exercise also protect the heart against pathological stress (Wei et al. 2014; Roh et al. 2016). As discussed below, examples include phosphoinositide-3kinase (PI3K) (McMullen et al. 2003; Weeks et al. 2012), Akt1 (Matsui et al. 1999, 2001; DeBosch et al. 2006), endothelial nitric oxide synthase (eNOS) (Calvert et al. 2011), peroxisome proliferator-activated receptor $\gamma$ coactivator $1 \alpha$ (PGC-1 $\alpha$ ) (Arany et al. 2006, 2008), C/EBP $\beta$ (Bostrom et al. 2010), and CITED4 (Bezzerides et al. 2016). Thus, it appears that pathways functionally important in the heart's response to exercise are enriched for pathways with the potential to mitigate disease phenotypes. Given this observation, the practical question emerges as to which of these pathways are amenable to therapeutic manipulation. MicroRNAs (miRNAs) may have some advantages as therapeutic targets. Both animal and clinical studies have shown the feasibility of targeting miRNAs in vivo, with chemically modified locked nucleic acid (LNA) inhibitors (Elmén et al. 2008; Janssen et al. 2013) and, at least in some cases, agonists (Wang et al. 2013; Yan et al. 2014). Thus, identification of miRNA pathways functionally important in the cardiac exercise re- 
sponse could in principle lay a foundation for new preventive or therapeutic approaches.

\section{CARDIAC PHENOTYPES INDUCED BY EXERCISE}

As a first step toward explaining what is known about the role of miRNAs in the cardiac response to exercise, we will briefly describe the major cardiac phenotypes induced by exercise and outline the molecular pathways thought responsible. We hope this background will provide a helpful context for the miRNA effects described later, as well as potentially highlight areas where influences by miRNAs may yet be discovered.

\section{Cardiac Changes in Response to Exercise}

In response to exercise training, the heart undergoes adaptive changes in both structure and function, resulting in what has been termed the "athlete's heart." These changes, which involve both the cardiomyocyte and noncardiomyocyte lineages of the heart, support the heart's ability to augment its output to perfuse exercising muscle and cope with the hemodynamic stress of exercise (Fig. 1). In humans, distinct patterns of cardiac adaptation have been described in response to different types of exercise from endurance to strength training (Baggish et al. 2008; Wasfy et al. 2015).

Most characteristics of the "athlete's heart" is cardiac hypertrophy. In response to exercise training, the left ventricular (LV) mass of the human heart can increase by $\geq 20 \%$ (DeMaria et al. 1978; Utomi et al. 2013). This effect, also a hallmark of animal models of exercise training, results primarily from cardiomyocyte hypertrophy (Ellison et al. 2012; McDiarmid et al. 2016). Cardiomyocytes can grow in length thus increasing LV volume (eccentric hypertrophy), in width thus increasing cardiac wall thickness (concentric hypertrophy), or a combination. Endurance exercise presents a volume challenge to the heart typically resulting in eccentric growth, whereas resistance exercise and the associated pressure overload characteristically causes concentric hypertrophy, although the
MicroRNAs in Cardiovascular Exercise Response

concentric nature of growth in resistancetrained athletes has been challenged by a recent meta-analysis (Utomi et al. 2013; Wilson et al. 2016). In animal models, studies have been largely confined to endurance training and we focus on this because the mechanistic pathways have been delineated in this context.

Exercise-induced hypertrophy appears to be "physiological" and largely distinct from the "pathological hypertrophy," which occurs in disease states such as chronic hypertension or HF following MI. "Pathological hypertrophy" in these states is part of an adverse remodeling process, including cardiac fibrosis, electrical remodeling, and activation of a fetal gene program (Molkentin et al. 1998; Dirkx et al. 2013). In contrast, exercise-induced "physiological hypertrophy" does not share these features, has a characteristic gene expression profile, including increased $\alpha$-to- $\beta$ myosin heavy-chain ratio, increased PGC- $1 \alpha$, and nonincreased atrial natriuretic peptide (ANP) and brain natriuretic peptide (BNP), and is generally associated with better clinical outcomes except potentially in extreme cases in ultra-elite athletes (La Gerche and Prior 2007; Bostrom et al. 2010; O’Keefe et al. 2012; Eijsvogels et al. 2016).

To support this increase in cardiac tissue and the heart's metabolic needs (increased ventricular work during exercise can cause LV oxygen demand to increase by sixfold), coronary blood flow, and, to a lesser extent, oxygen extraction increase. Enhanced cardiac perfusion results from both structural changes to the microvasculature (increased arteriole densities and/or diameters and capillary angiogenesis) and altered function (increased endothelium-dependent vasodilation) (White et al. 1998; Hambrecht et al. 2000; Duncker and Bache 2008).

In addition to their growth in size, cardiomyocytes change their functional characteristics in response to exercise. Both cardiomyocyte contraction and relaxation respond to exercise training. Cardiomyocyte longitudinal contraction per cycle (fractional shortening) can increase $40 \%-50 \%$ with exercise training, whereas the rates of relaxation and contraction can increase by $20 \%-40 \%$, with the degree of change correlating positively with the intensity of the 
X. Liu et al.

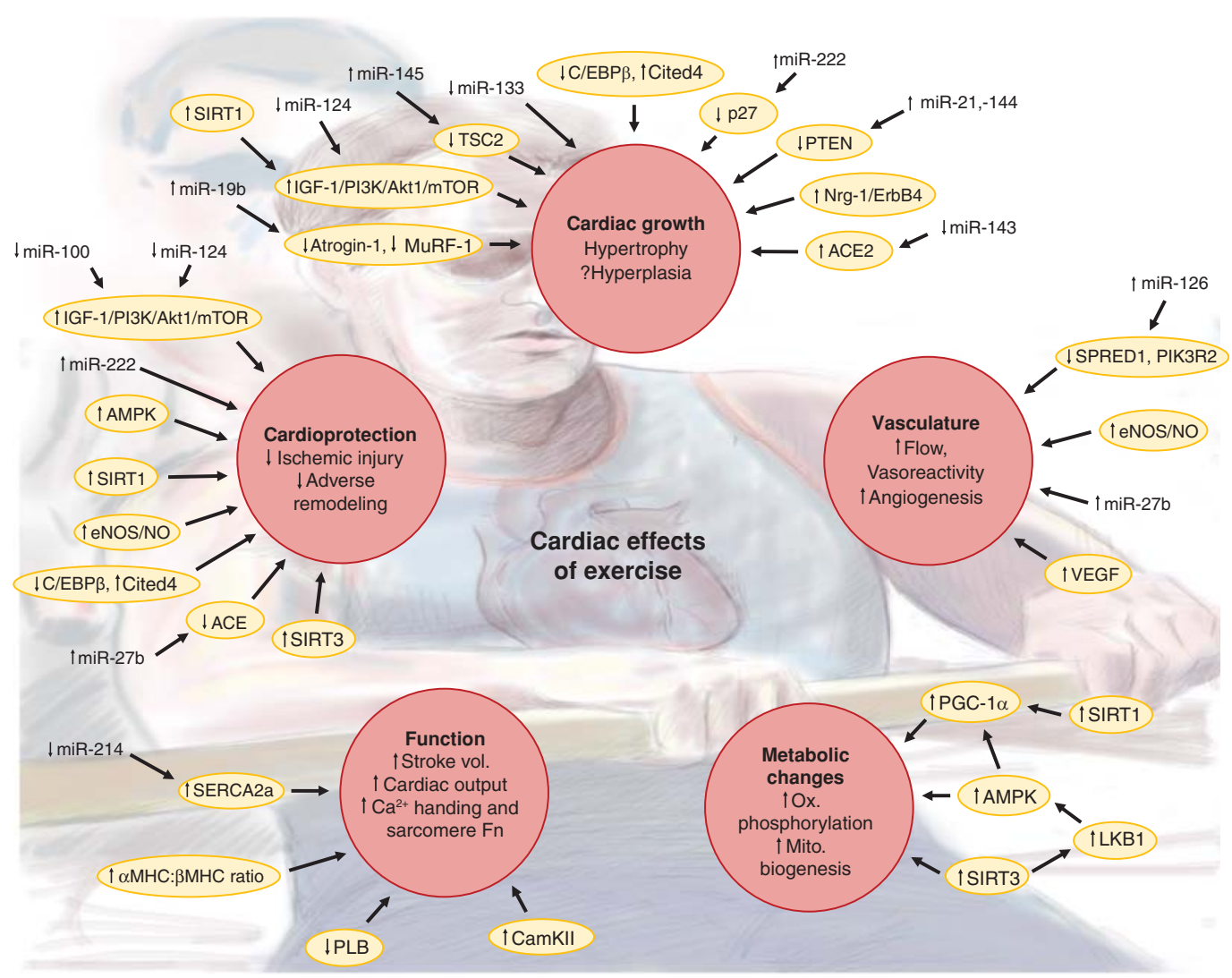

Figure 1. Cardiac phenotypes induced by exercise. Schematic illustrating the cardiac effects induced by chronic endurance exercise training. Red circles indicate major phenotypes or groups of phenotypes altered in response to exercise training. Yellow ovals indicate key proteins or pathways thought to contribute to the phenotype changes. Vertical arrows next to phenotypes, proteins/pathways, or microRNAs (miRNAs) indicate reported increases or decreases in response to exercise. For proteins/pathways, changes may be either in level or activity. Arrows connecting miRNAs, proteins/pathways, and phenotypes indicate regulation either demonstrated in animal models of exercise or inferred from in vitro experiments and/or in vivo experiments of related contexts. Stroke vol., Stroke volume; Sarcomere Fn, sarcomere function; Ox. phosphorylation, oxidative phosphorylation; Mito. biogenesis, mitochondrial biogenesis; ACE, angiotensin I converting enzyme; ACE2, angiotensin I converting enzyme 2; Akt1, AKT serine/threonine kinase 1; AMPK, AMP-activated kinase; CaMKII, calcium/ calmodulin-dependent protein kinase II; C/EBP $\beta$, CCAAT/enhancer binding protein $\beta$; Cited4, Cbp/p300 interacting transactivator with Glu/Asp rich carboxy-terminal domain 4; eNOS, endothelial nitric oxide synthase; ErbB4, erb-b2 receptor tyrosine kinase 4; IGF-1, insulin-like growth factor 1; LKB1, serine/threonine liver kinase B1; MHC, myosin heavy chain; mTOR, mechanistic target of rapamycin; MuRF-1, muscle-specific RING finger protein 1; NO; nitric oxide; Nrg-1, neuregulin 1; p27, cyclin-dependent kinase inhibitor 1B ( p27); PGC- $1 \alpha$, peroxisome proliferator-activated receptor $\gamma$ coactivator $1 \alpha$; PI3K, phosphoinositide-3-kinase; PIK3R2, phosphoinositide-3-kinase regulatory subunit 2; PLB, phospholamban; PTEN, phosphatase and tensin homolog; SERCA2a, sarcoplasmic reticulum calcium ATPase 2 isoform a; SIRT1, sirtuin 1; SIRT3, sirtuin 3; SPRED1, sprouty-related EVH1 domain-containing 1; TSC2, tuberous sclerosis 2; VEGF, vascular endothelial growth factor. 
exercise training (Kemi and Wisloff 2010). The maximal power output of individual cardiomyocytes is also increased (Diffee and Chung 2003). This contractile behavior of cardiomyocytes is regulated principally by $\mathrm{Ca}^{2+}$ dynamics. Plasma membrane depolarization triggers initial cytoplasmic $\mathrm{Ca}^{2+}$ entry through L-type calcium channels, in turn triggering $\mathrm{Ca}^{2+}$ release from the sarcoplasmic reticulum (SR) through ryanodine receptors. The increased cytoplasmic $\mathrm{Ca}^{2+}$ binds cardiac troponin $\mathrm{C}$, producing a conformation change in the actin-tropomyosin-troponin complex, which increases actinmyosin cross-bridge formation, resulting in contraction of the myofilaments and thus the cardiomyocytes. Relaxation is subsequently mediated by reuptake of cytoplasmic $\mathrm{Ca}^{2+}$ into the SR by the SR-Ca ${ }^{2+}$ ATPase-2a (SERCA2a). Exercise enhances cardiomyocyte contractility by increasing sensitivity to $\mathrm{Ca}^{2+}$ through several mechanisms, including activation of $\mathrm{Ca}^{2+} / \mathrm{cal}-$ modulin-dependent kinase II (CamKII) and isoform switching of troponins and myosin heavy chains, while promoting their relaxation by increasing SERCA2a activity through a combination of increased SERCA2a expression and phosphorylation of its inhibitor phospholamban (Wisloff et al. 2001; Kemi et al. 2007a). Exercise also mitigates the decreases in T-tubule (invaginations of the plasma membrane, which promote rapid and uniform depolarization and $\mathrm{Ca}^{2+}$ entry) density and organization observed in HF, thus promoting excitation-contraction coupling (ECC) (Kemi et al. 2011). For a more detailed discussion of how exercise affects contractility, please see Kemi and Wisloff (2010).

Exercise not only improves the function of the healthy heart but also protects the heart and promotes recovery from injury. In animals, exercise increases resistance to and improves recovery from a wide range of cardiac insults, including MI, pressure overload, diabetic cardiomyopathy, and doxorubicin cardiotoxicity (Chicco et al. 2006; Andrews Portes et al. 2009; Stolen et al. 2009; Barboza et al. 2013). Multiple mechanisms likely contribute to the benefits of exercise in these contexts, including protection against oxidative stress, increased resistance to apoptosis, restoration of $\mathrm{Ca}^{2+}$ handling and
MicroRNAs in Cardiovascular Exercise Response

contractile function, restoration of cardiac energy metabolism, inhibition of fibrosis, and vascular improvements (Wisloff et al. 2002; Matsui et al. 2003; Kemi et al. 2007b; Leosco et al. 2008; Calvert et al. 2011; Vettor et al. 2014).

Recent work has also raised the possibility that exercise may promote cardiomyogenesis. The adult mammalian heart was traditionally considered a nonmitotic organ, with essentially no formation of new cardiomyocytes beyond the early postnatal period. However, multiple studies have now shown that new cardiomyocytes do form, albeit at a low rate, throughout life (Bergmann et al. 2009; Senyo et al. 2013; Ali et al. 2014). Cardiomyogenesis appears to increase after injury (Smart et al. 2011; Senyo et al. 2013) and possibly exercise. We found in mice that exercise caused increases in markers of proliferation and cell-cycle activity (PCNA expression, positivity for Ki67, pHH3 and aurora B kinase staining, and BrdU incorporation) in cardiomyocytes (Bostrom et al. 2010), whereas others have reported that exercise caused increased numbers and activation of putative cardiac progenitor and stem-cell populations (Waring et al. 2014; Xiao et al. 2014). The source of newly formed cardiomyocytes in adulthood, whether from division of preexisting cardiomyocytes or cardiac progenitor cells, remains an area of controversy.

\section{Major Pathways Implicated in the Cardiac Exercise Response}

Several key pathways underlying the heart's response to exercise have been identified. Of these, perhaps the best established is the insulin-like growth factor 1 (IGF-1)/PI3K/Akt/ mTOR signaling axis. Exercise induces increased IGF-1 production in the heart (as well as other tissues), leading to increased autocrine and paracrine signaling (Neri Serneri et al. 2001; Frystyk 2010), which stimulates physiological cardiac hypertrophy (Reiss et al. 1996; McMullen et al. 2004). Cardiac-specific IGF-1 receptor (IGF-1R) knockout mice show that IGF-1R signaling is necessary for exercise-induced hypertrophy (Kim et al. 2008). The PI3K family of enzymes appear to be the immediate downstream mediators of these signals: Genetic manipulations of 
X. Liu et al.

the $110 \alpha$ PI3K isoform show it is necessary and sufficient for exercise-induced physiological cardiac hypertrophy but not pathological hypertrophy (Shioi et al. 2000; McMullen et al. 2004; Weeks et al. 2012). Similarly, Akt1 appears to be the PI3K effector that is both necessary and sufficient for physiological hypertrophy while actually inhibiting pathological hypertrophy induced by pressure overload (DeBosch et al. 2006). Conversely, levels of the phosphatase and tensin homolog (PTEN), which inhibits $\mathrm{PI} 3 \mathrm{~K} /$ Akt signaling, decrease in the heart in response to exercise (Ma et al. 2013; Pons et al. 2013). We found that increased Akt1 expression in cardiomyocytes causes a decrease in expression of the transcription factor $\mathrm{C} / \mathrm{EBP} \beta$, and mice heterozygous for $\mathrm{C} / \mathrm{EBP} \beta$ deletion recapitulate many of the cardiac phenotypes seen with exercise and are resistant to pressure-overload-induced cardiac dysfunction (Bostrom et al. 2010). C/EBP $\beta$ appears to act through repressing expression of the protein CITED4 (Bostrom et al. 2010), and mice with inducible cardiac-specific overexpression of CITED4 develop cardiac hypertrophy reminiscent of the "athlete's heart" as well as improved recovery from cardiac ischemia-reperfusion injury (IRI), effects that appear to be the result of increased mTORC1 activity (Bezzerides et al. 2016). Exercise also appears to increase $\mathrm{mTORC} 1$ activity by causing a decrease in expression of its inhibitor TSC2 (Ma et al. 2013) and by increasing phosphorylation of mTOR (Kemi et al. 2008). In addition to its effect on cardiac hypertrophy, Akt signaling also contributes to the resistance of cardiomyocytes to apoptosis on injury (Matsui et al. 1999, 2001).

Other exercise-activated pathways also contribute to increasing the resistance of the heart to injury. Neuregulin-1 (NRG-1), which is induced by exercise, binds to ErbB receptors on cardiomyocytes and has cardioprotective effects against IRI via a PI3K/Akt-dependent mechanism (Fang et al. 2010; Cai et al. 2016). NRG-1 has also been reported to stimulate cardiomyocyte proliferation and to induce angiogenesis. These effects have led to clinical trials evaluating the use of recombinant NRG-1 fragments for HF treatment (Bersell et al. 2009; Odiete et al.
2012). eNOS activity increases in response to exercise, as a result of both increased circulating catecholamines and increased phosphorylation by Akt and AMP-activated kinase (AMPK) (Zhang et al. 2009; Calvert et al. 2011) and appears important in protection against ischemic injury and oxidative stress. Exercise also induces expression of the deacetylases, Sirt1 and Sirt3, which regulate Akt, AMPK, and PGG-1 $\alpha$ among other pathways and protect against cardiac IRI as well as oxidative stress, with Sirt3 also protecting against pathological cardiac hypertrophy and fibrosis (Ferrara et al. 2008; Sundaresan et al. 2009; Hsu et al. 2010; Pillai et al. 2010; Lai et al. 2014).

\section{miRNAs IN THE CARDIAC EXERCISE RESPONSE}

miRNAs are small ( $\sim 22$ nucleotides) noncoding RNAs that modulate gene expression by RNA silencing and posttranscriptional repression (Bartel 2004). miRNAs play pivotal roles in cardiovascular development and disease (Zhao et al. 2005; van Rooij et al. 2006; Small and Olson 2011; Da Costa Martins and De Windt 2012; Wang and Yang 2012) and thus investigating their roles in exercise-induced cardiac phenotypes is logical. Multiple studies document miRNAs in the heart or circulation that are differentially regulated in response to exercise and, in some instances, functional contributions can be reasonably inferred from alterations in their known targets. However, efforts to assess the functional roles of cardiac or circulating miRNAs in exercise-induced cardiac phenotypes are relatively recent (Fernandes et al. 2011; Soci et al. 2011; Liu et al. 2015).

\section{miRNAs DYNAMICALLY REGULATED BY EXERCISE}

\section{Cardiac miRNAs}

Many miRNAs are altered in hearts after exercise or the manipulation of physiological hypertrophy pathways (Fig. 2A,B; Table 1). Care and colleagues found that miR-1 and -133 are down-regulated in rat hearts by treadmill train- 
A

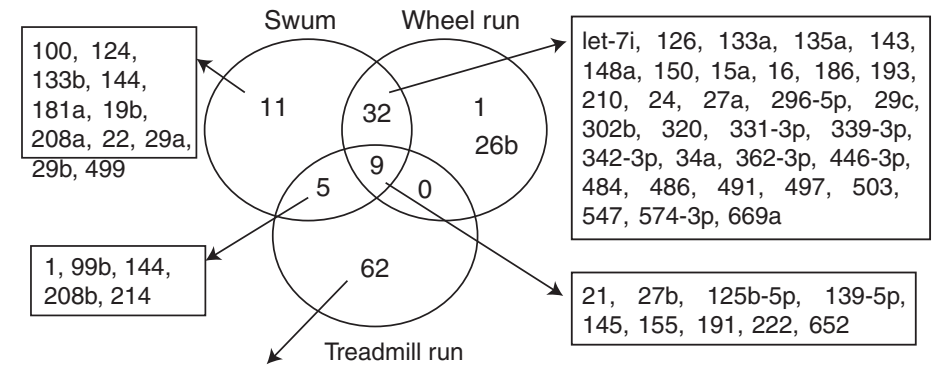

let-7d-3p, 130a-5p, 130b-3p, 132-3p, 133, 136-5p, 140-3p, 140-5p, 141-5p, 146-5p, $146 b-5 p, 149-5 p, 152-5 p, 187-3 p$, 1894-3p, 1901, 192-5p, 195-5p, 199a-3p, 199a-5p, 212-3p, 214-5p, 216b-5p, 217-5p, 220-1, 221-3p, 222-5p, 223-3p, 223-5p, 224-5p, 224-3p, 23b-3p, 24-2-5p, 27a-5p, 28-3p, 29b-2-5p, 31a-3p, 31a-5p, 324-3p, 324-5p, 336-5p, 34a-3p, 376a-3p, 376c-3p, 384-3p, 409a-3p, 441-3p, 412-3p, 421-3p, 425-3p, 429, 455-5p, 466c-5p, 485-3p, 541-5p, 598-3p, 664-3p, 674-3p, 687, 694, 701-5p, 9a-1

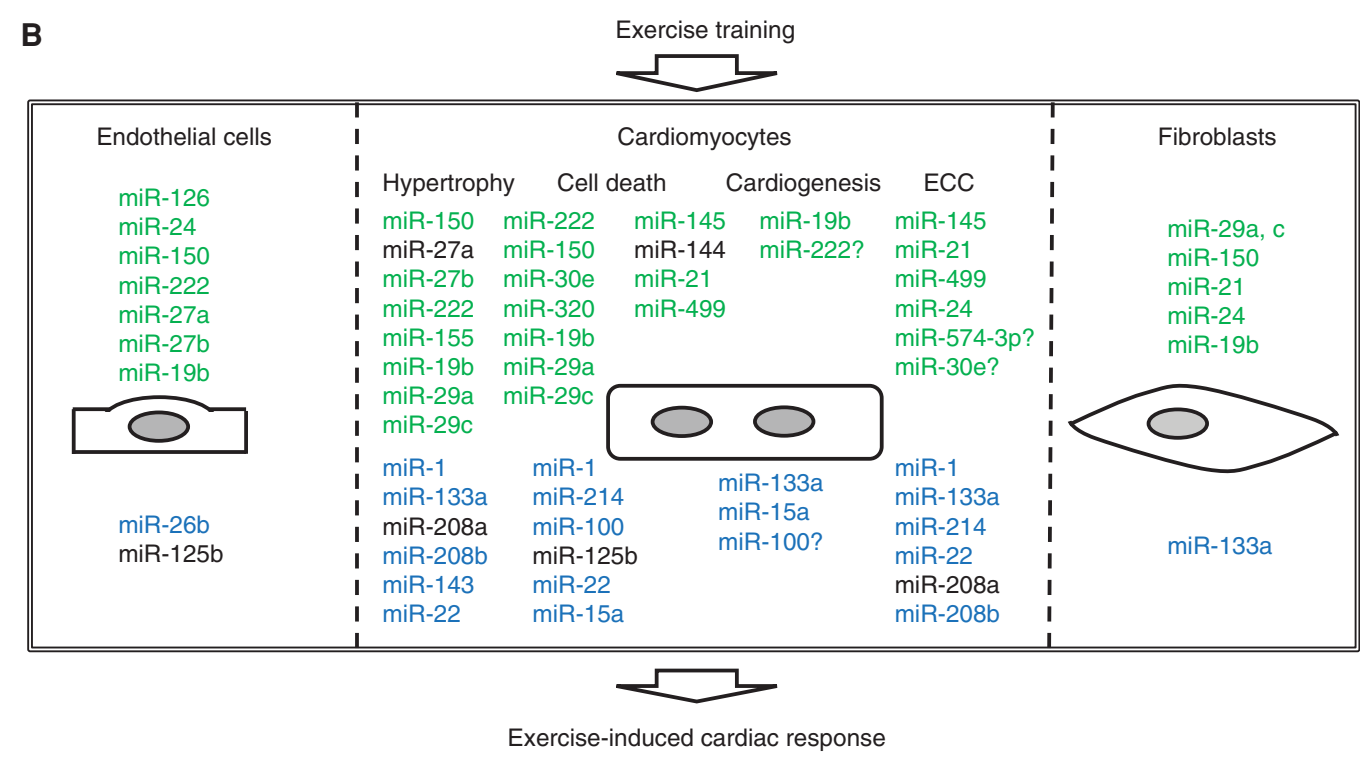

Figure 2. MicroRNAs (miRNAs) dynamically regulated in the heart by exercise training. (A) 120 miRNAs are clustered according to their reported expression altered by different exercise training in the heart. $(B)$ miRNAs marked in green or blue have been reported to be up-regulated or down-regulated after exercise, respectively. The responses of miRNAs marked in black have been reported to vary depending on the health of the animals and/or the timing and exercise model studied. ECC, Excitation-contraction coupling.

ing as well as in transgenic mice with cardiac overexpression of Akt1 (Care et al. 2007), which as noted above is necessary and sufficient for physiological hypertrophy. Lin et al. profiled mouse hearts with genetic manipulation of $\operatorname{PI} 3 \mathrm{~K}(\mathrm{p} 110 \alpha)$ at baseline and after ischemic stress. They found that miR-222, $-34 \mathrm{a}$, and -210 were down-regulated in PI3K-induced physiological hypertrophy and up-regulated in dominant-negative PI3K transgenic hearts (Lin et al. 2010). Ma and colleagues studied miRNAs in rats subjected to 8 weeks of swim training. Cardiac expression of miR-21, -144, and -145 increased while miR-124 decreased (Ma et al. 2013). Correspondingly, in exercised hearts, PTEN (targeted by miR-21 and miR-144) and TSC2 (targeted by miR-145) were decreased while $\mathrm{PI} 3 \mathrm{~K}(110 \alpha)$ (targeted by miR-124) was 
X. Liu et al.

Table 1. miRNAs altered in exercise and their putative functional effects and targets

\begin{tabular}{|c|c|c|c|}
\hline miRNA & Putative targets & Functional effects & References (PMID) \\
\hline miR-1 & $\begin{array}{l}\text { PKC } \varepsilon, \text { HSP60, BCL2, GATA4, } \\
\text { MEF2A, NCX1 }\end{array}$ & $\begin{array}{l}\text { Antihypertrophic, increased CM death, } \\
\text { ECC }\end{array}$ & $\begin{array}{l}\text { PMID: } 19506341, \\
\text { PMID: } 23226300, \\
\text { PMID: } 21447748, \\
\text { PMID: } 17468766, \\
\text { PMID: } 26646371\end{array}$ \\
\hline miR-100 & IGF-1R & Increased CM death & $\begin{array}{l}\text { PMID: 25793527, } \\
\text { PMID: } 26191255\end{array}$ \\
\hline $\operatorname{miR}-125 b-5 p$ & p53, Bak1, TRAF6 & Reduced CM death, profibrosis & $\begin{array}{l}\text { PMID: } 25863248, \\
\text { PMID: } 26408546, \\
\text { PMID: } 24576954\end{array}$ \\
\hline miR-126 & Spred1, PIK3R2 & Increased angiogenesis & $\begin{array}{l}\text { PMID: } 22330028, \\
\text { PMID: } 25863248\end{array}$ \\
\hline $\operatorname{miR}-133 a$ & $\begin{array}{l}\text { RhoA, DAPK2, Cdc42, Nelf- } \\
\text { A/WHSC2 }\end{array}$ & $\begin{array}{l}\text { Antihypertrophic, ECC, antifibrotic, } \\
\text { anticardiomyogenesis }\end{array}$ & $\begin{array}{l}\text { PMID: } 17468766, \\
\text { PMID: } 21447748\end{array}$ \\
\hline $\operatorname{miR}-143$ & ACE2 & Prohypertrophic & $\begin{array}{l}\text { PMID: } 21709209 \\
\text { PMID: } 24751578\end{array}$ \\
\hline miR-144 & Rac1, PTEN & Inhibited CM death & $\begin{array}{l}\text { PMID: } 23812090 \\
\text { PMID: } 26408546\end{array}$ \\
\hline $\operatorname{miR}-145$ & TSC2, Bnip3, CaMKIII & $\begin{array}{l}\text { Inhibited CM death, ECC, promoting } \\
\text { autophagy }\end{array}$ & $\begin{array}{l}\text { PMID: 23812090, } \\
\text { PMID: 26408546, } \\
\text { PMID: 23028672, } \\
\text { PMID: 23702479, } \\
\text { PMID: } 26432843\end{array}$ \\
\hline $\operatorname{miR}-150$ & SRF, Egr2, p2x7r, c-myb, & $\begin{array}{l}\text { Inhibited CM death, ECC, antifibrosis, } \\
\text { antihypertrophic }\end{array}$ & $\begin{array}{l}\text { PMID: } 24751578, \\
\text { PMID: } 25863248, \\
\text { PMID: } 25639779, \\
\text { PMID: } 25824147, \\
\text { PMID: } 27184887\end{array}$ \\
\hline miR-155 & SOCS-1, Jarid2 & Increased CM death, antihypertophy & $\begin{array}{l}\text { PMID: } 25863248, \\
\text { PMID: } 26408546, \\
\text { PMID: } 24657879\end{array}$ \\
\hline $\operatorname{miR}-15 a$ & CHEK1 & Increased CM death, anticardiogenesis & $\begin{array}{l}\text { PMID: } 25863248, \\
\text { PMID: } 22052914, \\
\text { PMID: } 24043355\end{array}$ \\
\hline miR-181a & MAPK1, TNF- $\alpha$, GAT4 & Inflammation injury & PMID: 25793527 \\
\hline miR-19b & $\begin{array}{l}\text { Bim, TNF- } \alpha, \text { PTEN, MuRF, } \\
\text { atrogin-1, CTGF, TSP-1 }\end{array}$ & $\begin{array}{l}\text { Prohypertrophy, inhibited CM death, } \\
\text { cardiogenesis, antifibrosis, } \\
\text { antiangiogenesis }\end{array}$ & $\begin{array}{l}\text { PMID: } 25793527, \\
\text { PMID: } 26918829, \\
\text { PMID: } 24117217, \\
\text { PMID: } 21501375\end{array}$ \\
\hline miR-208a & THARAP1, myostatin, GATA4, & Prohypertrophic, ECC & $\begin{array}{l}\text { PMID: 27503950, } \\
\text { PMID: } 25793527, \\
\text { PMID: } 19726871, \\
\text { PMID: } 17379774\end{array}$ \\
\hline $\operatorname{miR}-208 b$ & THARAP1, myostatin, & Prohypertrophic, ECC & PMID: 27503950 \\
\hline $\operatorname{miR}-21$ & PTEN, PDCD4, FasL, Spry1, & $\begin{array}{l}\text { Inhibited CM death, profibrosis, } \\
\text { proangiogenesis }\end{array}$ & $\begin{array}{l}\text { PMID: } 23812090, \\
\text { PMID: } 19043405, \\
\text { PMID: } 19041309\end{array}$ \\
\hline $\operatorname{miR}-214$ & $\begin{array}{l}\text { SERCA2a, Ncx1, BIM, CypD, } \\
\text { CaMKII }, \text { XBP1 }\end{array}$ & $\begin{array}{l}\text { Inhibited CM death, ECC, } \\
\text { antiangiogenesis }\end{array}$ & $\begin{array}{l}\text { PMID: 22426211, } \\
\text { PMID: 25822872, } \\
\text { PMID: 26646371, }\end{array}$ \\
\hline
\end{tabular}

Continued 
MicroRNAs in Cardiovascular Exercise Response

Table 1. Continued

\begin{tabular}{|c|c|c|c|}
\hline miRNA & Putative targets & Functional effects & References (PMID) \\
\hline & & & $\begin{array}{l}\text { PMID: 26408546, } \\
\text { PMID: } 25656649\end{array}$ \\
\hline $\operatorname{miR}-22$ & $\begin{array}{l}\text { CBP, CDK16, Sirt1, Sp1, } \\
\text { PTEN, PURB, Hdac4 }\end{array}$ & $\begin{array}{l}\text { Prohypertrophic, inhibiting CM death, } \\
\text { ECC }\end{array}$ & $\begin{array}{l}\text { PMID: } 25793527 \\
\text { PMID: } 22570371\end{array}$ \\
\hline miR-222 & p27, HIPK1/2, Hmbox1 & $\begin{array}{l}\text { Increased CM proliferation, } \\
\text { prohypertrophy, inhibited CM death, } \\
\text { antiangiogenesis }\end{array}$ & $\begin{array}{l}\text { PMID: } 25863248 \\
\text { PMID: } 26408546\end{array}$ \\
\hline $\operatorname{miR}-24$ & $\begin{array}{l}\text { Bim, BCL2L11, Bax, GATA2, } \\
\text { PAK4, Furin }\end{array}$ & $\begin{array}{l}\text { Inhibited CM death, ECC, antiangiogenesis, } \\
\text { antifibrosis }\end{array}$ & $\begin{array}{l}\text { PMID: } 25863248, \\
\text { PMID: } 26408546, \\
\text { PMID: } 21383058, \\
\text { PMID: } 21788589, \\
\text { PMID: } 22260784\end{array}$ \\
\hline $\mathrm{miR}-26 \mathrm{~b}$ & GATA4, IGF & $\begin{array}{l}\text { Antiangiogenic, increased CM death, } \\
\text { antihypertrophic }\end{array}$ & PMID: 24751578 \\
\hline $\operatorname{miR}-27 a$ & ACE, SEMA6A & Prohypertrophic, proangiogenesis & $\begin{array}{l}\text { PMID: } 21709209, \\
\text { PMID: } 24751578, \\
\text { PMID: } 26408546, \\
\text { PMID: } 25863248, \\
\text { PMID: } 22184411\end{array}$ \\
\hline $\operatorname{miR}-27 b$ & ACE, SEMA6A & Prohypertrophic, proangiogenesis & $\begin{array}{l}\text { PMID: } 21709209, \\
\text { PMID: } 26408546, \\
\text { PMID: } 25863248, \\
\text { PMID: } 22184411\end{array}$ \\
\hline miR-29a & $\begin{array}{l}\text { COL1A1, COL1A2, COL3A1, } \\
\text { FBN1, ELN, Mcl-2 }\end{array}$ & $\begin{array}{l}\text { Antifibrotic, increased CM death, } \\
\text { prohypertrophy }\end{array}$ & $\begin{array}{l}\text { PMID: } 21447748 \\
\text { PMID: } 24642957 \\
\text { PMID: } 18723672 \\
\text { PMID: } 17108080\end{array}$ \\
\hline $\operatorname{miR}-29 c$ & $\begin{array}{l}\text { COL1A1, COL1A2, COL3A1, } \\
\text { FBN1, ELN, Mcl-2 }\end{array}$ & $\begin{array}{l}\text { Antifibrotic, increased CM death, } \\
\text { prohypertrophy }\end{array}$ & $\begin{array}{l}\text { PMID: } 21447748 \\
\text { PMID: } 24642957 \\
\text { PMID: } 18723672 \\
\text { PMID: } 17108080\end{array}$ \\
\hline $\operatorname{miR}-30 \mathrm{e}$ & ?CaMKII\&, ?Egfr1, ?Bcl2 & ?ECC, ?apoptosis & PMID: 25793527 \\
\hline $\operatorname{miR}-320$ & HSP20 & Increased CM death & $\begin{array}{l}\text { PMID: } 19380620 \text {, } \\
\text { PMID: } 25863248\end{array}$ \\
\hline miR-499 & CaN, Drp1 & Inhibited CM death, ECC & $\begin{array}{l}\text { PMID: 26387191, } \\
\text { PMID: } 21186368\end{array}$ \\
\hline $\operatorname{miR}-574-3 p$ & ATP2A2 & ECC & PMID: 25863248 \\
\hline
\end{tabular}

MicroRNAs (miRNAs) implicated in the cardiac response to exercise. miRNAs reported as dynamically regulated by exercise and potentially contributing functionally to the phenotypes associated with exercise are listed, along with their putative targets and functional effects, as well as supporting citations.

CM, Cardiomyocyte; ECC, excitation-contraction coupling; PTEN, phosphatase and tensin homolog; IGF-1R, insulin-like growth factor receptor.

increased (Ma et al. 2013). These data suggest at least some of the miRNAs altered by exercise modulate $\mathrm{PI} 3 \mathrm{~K} / \mathrm{AKT} / \mathrm{mTOR}$ signaling, a key regulator of the cardiac response to exercise.

Soci and colleagues profiled 349 cardiac miRNAs after 10 weeks of exercise and found
87 differentially expressed compared with sedentary controls, including 48 up-regulated and 39 down-regulated miRNAs (Soci et al. 2011). miR-1, -133a, and -133b, all previously shown to be involved in pathological and stress-responsive cardiac hypertrophy, decreased after exercise 
X. Liu et al.

training (Care et al. 2007; Soci et al. 2011). Conversely, miR-29c was increased in exercised hearts compared with sedentary controls (Soci et al. 2011). In exercised rats, miR-27a and -27b were reported to increase while miR-143 decreased, together with reciprocal changes in expression of their angiotensin-converting enzyme targets, ACE and ACE2, respectively, suggesting specific miRNAs targeting renin-angiotensin system genes are dynamically modulated by exercise training and may contribute, at least in part, to the progression of cardiac hypertrophy (Fernandes et al. 2011). Using a microarray to assess $>1000$ murine miRNAs in exercise-induced LV hypertrophy, Martinelli et al. (2014) identified 35 miRNAs differentially expressed after 1 week of exercise relative to sedentary controls and 25 miRNAs differentially expressed after 5 weeks of training, documenting temporal regulation of cardiac miRNAs during exercise training. We profiled miRNAs in hearts of mice subjected to 3 weeks of either an intense swimming protocol or voluntary wheel running. We found 124 miRNAs that were differentially expressed in hearts from wheel-run mice and 55 differentially expressed in hearts from swum mice in comparison to sedentary controls (Liu et al. 2015). It is worth noting that forced swim training may cause a stress response not present in voluntary wheel running. Among these, 16 miRNAs, including miR-222, were independently validated as concordantly regulated in both models (Liu et al. 2015). In a recent study, Ramasamy et al. (2015) sequenced RNA from the hearts of rats swum for 8 weeks and sedentary controls and found that $>80 \%$ of the 201 detected miRNAs were differentially regulated. Among the 128 miRNAs with read counts of $>1000,95$ miRNAs were altered $>1.5$-fold with an adjusted false discovery rate (FDR) $<0.1$ (Ramasamy et al. 2015). miRNAs changed $>2.5$-fold were miR208a, $-19 b,-133 b$, and $-30 e$, which were all upregulated, and miR-99b, -100, -191a, -22 , and -181a, which were all down-regulated. Gene ontology and pathway mapping suggested that these miRNAs are associated with cardiac hypertrophy and apoptosis (Ramasamy et al. 2015).

Some studies have examined the effects of exercise on miRNA expression in the context of cardiac pathologies such as HF. Souza et al. (2015) examined cardiac miRNAs in controls and failing animals subjected to exercise training or sedentary. Only 11 miRNAs were specifically altered by exercise in the failing hearts, whereas 23 miRNAs were concordantly altered in both sedentary and exercised HF hearts (Souza et al. 2015). Of note, miR-222 was upregulated in both HF groups (Souza et al. 2015). Other miRNAs, including miR-1, -29, -126, and -214 , have also been reported to change in both healthy and diseased hearts after exercise (da Silva et al. 2012; Melo et al. 2014, 2015a,b; Zhao 2015). Given limited access to tissue, there are no clinical studies to date examining human cardiac miRNA alterations after exercise.

\section{Circulating miRNAs}

Extracellular miRNAs, packaged in lipid microparticles such as exosomes, microvesicles, and apoptotic bodies or associated with protein complexes like RNA-binding proteins (argonaute 2, nucleophosmin 1) and high-density lipoproteins (HDLs), are widely present in body fluids such as plasma (Valadi et al. 2007; Wang et al. 2010; Arroyo et al. 2011; Turchinovich et al. 2011). Such circulating miRNAs have attracted interest as potential biomarkers for a variety of diseases (Mitchell et al. 2008; Akat et al. 2014; Galimberti et al. 2014). Recent studies have also suggested that circulating miRNAs may mediate intercellular communication (Valadi et al. 2007; Zernecke et al. 2009; Hergenreider et al. 2012). Baggish and colleagues examined the response of eight human plasma miRNAs to acute exhaustive exercise and sustained aerobic exercise training in healthy collegiate athletes. They found that plasma levels of miR-146a and -222 increased after acute exercise both before and after sustained training, whereas miR-21 and -221 were up-regulated only by acute exercise before sustained training, and miR-20a increased after sustained training but not acute exercise (Baggish et al. 2011). Strong correlations were seen between changes in both resting miR-20a and peak exercise levels of miR-146a and $V_{\mathrm{O} 2 \max }$ (Baggish et al. 2011). We found that serum miR-222 also increased in 
HF patients after acute exercise (Liu et al. 2015). It is interesting to note that some of the miRNAs altered in human peripheral blood after exercise are altered in the hearts of animals after exercise training. Taken together, these data suggest a parallel that may reflect conservation of exercise-responsive miRNA pathways.

Among muscle-enriched miRNAs (miR-1, $-133 \mathrm{a},-133 \mathrm{~b},-206,-208 \mathrm{~b}$, and -486), only miR-486 was altered (decreased) in response to acute and chronic cycling exercise in young men (Aoi et al. 2013). Conversely, Gomes et al. (2014) found that circulating miR-1, -133 , and -206 levels increased after a half-marathon. Mooren et al. (2014) also showed that plasma levels of miR-1, -133, -206, -499, and -206 increased after running a marathon. Intriguingly, alterations of miR-1, -133a, and -206 correlated not with cardiac injury markers but aerobic performance (Mooren et al. 2014). Sawada et al. (2013) reported that miR-149* increased, whereas miR146a and -221 decreased in human serum 3 days after acute resistance exercise. Changes in circulating miRNAs levels appear to depend on the type of exercise, as Wardle et al. (2015) found that elite endurance athletes had higher plasma miR-222 levels than sedentary controls while elite strength athletes had lower levels, and Uhlemann et al. (2014) found that circulating miR-126 increased in response to endurance but not resistance training. Studies of alterations in plasma or serum miRNA in response to exercise have thus far been confined in humans. Although the observation that some circulating miRNAs altered in exercise coincide with miRNAs documented in animal models to be dynamically regulated or functionally important in the heart is encouraging, the tissue source(s) and role(s) of circulating miRNAs induced by exercise have yet to be defined. Moreover, their clinical value as biomarkers reflecting fitness or cardiometabolic risk remains to be established.

\section{FUNCTIONAL CONTRIBUTIONS OF MIRNAs TO EXERCISE PHENOTYPES}

\section{Cardiac Hypertrophy}

As noted above, cardiac hypertrophy can be divided into pathological and physiological hy-
MicroRNAs in Cardiovascular Exercise Response

pertrophy. miRNAs modulating pathological cardiac hypertrophy have been well studied and include both antagonists and agonists (Ucar et al. 2012; Yang et al. 2013; Bang et al. 2014; for detailed reviews, see Da Costa Martins and De Windt 2012; Wang and Yang 2012). In contrast, fewer studies have directly examined the functional role of miRNAs in physiological cardiac hypertrophy (Fernandes et al. 2011; Soci et al. 2011; Liu et al. 2015). However, multiple studies have identified cardiac miRNAs differentially regulated in exercise, which were known to regulate pathological hypertrophy, including miRNAs in Table 1 (Care et al. 2007; Fernandes et al. 2011; Soci et al. 2011; Ma et al. 2013; Martinelli et al. 2014; Liu et al. 2015). Thus, although the functional contributions of most have not been directly assessed in exercise-induced hypertrophy, these miRNAs may also modulate physiological hypertrophy. However, because the pathways mediating pathological and physiological hypertrophy are often distinct, the directionality of their influence may not be readily extrapolated from studies of pathological hypertrophy. For example, cardiac Aktl is activated in both physiological and pathological hypertrophy models but appears necessary for the former and actually inhibitory of the latter (DeBosch et al. 2006), and thus plays a beneficial role in both settings. Similarly, our unpublished data suggest that miR-222, which is up-regulated in both physiological and pathological hypertrophy, is necessary for physiological growth but may inhibit pathological growth, again playing a positive role in both settings.

Care et al. (2007) found that cardiac miR133 decreased in trained rats and in patients with heart disease. In vivo inhibition of miR133 induced marked and sustained cardiac hypertrophy, suggesting that miR-133 acts as an inhibitor of cardiac hypertrophy (Care et al. 2007). Soci et al. (2011) also found decreased expression of cardiac miR-133a and miR-133b in rats after 10 weeks of swimming. In contrast, others found increased miR-133b in the hearts of rats after 8 weeks of swimming (Ramasamy et al. 2015). Whether this discrepancy is caused by differences in the exercise protocols or measurement methodologies is not clear. 
X. Liu et al.

We found that cardiac miR-222 was up-regulated both by swimming and voluntary wheel running in mice (Liu et al. 2015). miR-222 expression in neonatal cardiomyocytes in vitro produced cellular proliferation and hypertrophy with a gene expression pattern characteristic of physiological growth. In contrast, miR222 inhibition reduced cardiomyocyte size and proliferation in neonatal cardiomyocytes (Liu et al. 2015). In vivo, neither miR-222 inhibition nor overexpression altered cardiac or cardiomyocyte size. However, miR-222 inhibition completely blocked the increase of cardiomyocyte and heart size induced by 3 weeks of intensive exercise as well as reduced the markers of cell proliferation induced by exercise (Liu et al. 2015). Mechanistically, HMBOX1, p27, HIPK1, and HIPK2 were implicated as direct targets contributing to miR-222's effects in cardiomyocytes (Liu et al. 2015). Taken together, these data suggest that miR-222 is necessary for exerciseinduced cardiac growth. Exercise induction of cardiac miR-19b has also been reported by others to induce cardiomyocyte hypertrophy by targeting atrogin-1 and MuRF-1, as well as enhancing calcineurin/NFAT signaling (Song et al. 2014; Ramasamy et al. 2015).

\section{Cardiomyocyte Hyperplasia}

Short-term physiological changes in heart size are mostly the result of corresponding changes in cardiomyocyte size. However, work from our group (Bostrom et al. 2010; Liu et al. 2015) and others (Waring et al. 2014; Xiao et al. 2014) has raised the possibility that exercise may also induce cardiomyocyte hyperplasia or cardiomyogenesis, perhaps in parallel to the neurogenesis well documented in animals after exercise (van Praag et al. 1999, 2005). miR-222 expression increased proliferation of neonatal cardiomyocytes in vitro and increased markers of proliferation in adult cardiomyocytes in vivo after ischemic injury (Liu et al. 2015). Conversely, an LNA anti-miR inhibitor specific to miR-222 blocked the increase in cardiomyocyte proliferation markers seen after exercise in control animals (Liu et al. 2015). These studies intriguingly raise the possibility that exercise is an inductive physiological cue regulating cardiomyogenesis in the adult heart, and that miR-222 may be part of the pathway regulating this response. Intriguingly, Li et al. (2016) recently reported that knockdown of endogenous miR-199 up-regulates its target PGC- $1 \alpha$ and causes physiological cardiac and cardiomyocyte hypertrophy as well as an increase in markers of cardiomyocyte proliferation. However, it should be emphasized that the precise degree to which new cardiomyocytes are formed, survive, and contribute functionally to the benefits of exercise in animal models, let alone humans, remains unclear.

Although little is known about other miRNAs regulating cardiomyogenesis after exercise, other studies have suggested that miRNAs may regulate cardiomyogenesis in other settings. Eulalio et al. (2012) examined the ability of human miRNA mimics to induce proliferation of rat neonatal cardiomyocytes in vitro, and then examined the effects of the most promising candidates in adult rat cardiomyocytes in vitro and in a murine model of ischemic injury in vivo. Interestingly, they found that miR-590 and -199a promoted cell-cycle reentry of adult cardiomyocytes in vitro and markers of cardiomyocyte proliferation after ischemic injury in vivo (Eulalio et al. 2012). In addition, Chen et al. (2013) showed that the mir-17-92 cluster (specifically miR-19) is necessary and sufficient to induce markers of cardiomyocyte proliferation in adult hearts. Again, it is difficult to precisely document the degree of cardiomyogenesis and correlate this with functional benefits in vivo, leaving open the possibility that these benefits accrue from other functional effects, such as inhibition of cardiomyocyte death, which often appears to coincide with drivers of growth and proliferation. Nevertheless, it appears that identification of miRNAs that induce cardiomyocyte proliferation in vitro and/or in vivo may enrich miRNAs with beneficial effects on cardiac function and repair in vivo (Eulalio et al. 2012; Li et al. 2016).

\section{Excitation-Contraction Coupling}

Exercise training decreases miR-1, -22, -133, -208 , and -214 and increases miR-24, -145, 
-499 , and $-574-3 p$ in healthy hearts, although it appears to restore miR-1 and -214 and increase miR-145 in HF (Care et al. 2007; Cha et al. 2013; Liu et al. 2015; Melo et al. 2015a,b; Ramasamy et al. 2015; Souza et al. 2015; Zhao 2015). Intriguingly, these miRNAs have been implicated in regulating ECC, suggesting that miRNAs contribute to exercise-induced ECC remodeling. For example, Cha et al. (2013) showed that miR-145 suppressed reactive oxygen species (ROS)-induced $\mathrm{Ca}^{2+}$ overload and related signaling by targeting CaMKIIס, and thereby protected against ROS-induced cardiomyocyte apoptosis. Resistance training decreased the expression of miR-214 contributing to up-regulation of its target, SERCA2a, which enhances SR $\mathrm{Ca}^{2+}$-uptake accelerating cardiomyocyte relaxation and loading the SR with $\mathrm{Ca}^{2+}$, thereby improving peak $\mathrm{Ca}^{2+}$ release and contractility (Melo et al. 2015a). Melo et al. (2015b) also found that swimming increased miR-1 (targeting NCX1) and decreased miR-214 (targeting NCX1 and SERCA2a) regulating $\mathrm{Ca}^{2+}$ handling after MI.

\section{Cardioprotection from Ischemic Injury}

Exercise protects against acute myocardial ischemic injury in animals and humans (Powers et al. 2002, 2008; Lennon et al. 2004; Calvert et al. 2011). Many of the miRNAs identified as altered in exercised hearts have documented roles regulating apoptosis or necroptosis, and therefore could provide mechanistic links between exercise and cardioprotection (Fig. 2B) (Cheng et al. 2009; Dong et al. 2009; Lin et al. 2010; Wang et al. 2011; Ma et al. 2013; Martinelli et al. 2014; Liu et al. 2015; Ramasamy et al. 2015; Zhao 2015; Qin et al. 2016). However, functional effects in cardiomyocytes in vitro or in vivo have only been investigated in a minority of cases and only rarely has cardioprotection against ischemic injury been investigated. Aurora and colleagues reported that miR-214 protects the mouse heart from ischemic injury by mitigating $\mathrm{Ca}^{2+}$ overload and cell death (Aurora et al. 2012). Ramasamy et al. (2015) found that physiological hypertrophy increases cardiac miR-19b, which others have
MicroRNAs in Cardiovascular Exercise Response

shown down-regulates proapoptotic BIM, thereby protecting cardiomyocytes against ERstress-induced apoptosis (Song et al. 2014). Whether exercise-induced miR-19b contributes to acute cardioprotection in vivo has not been reported but seems probable. Other intriguing candidates include miR-100, which is downregulated by exercise (Ramasamy et al. 2015), which in vitro can protect cardiomyocytes against $\mathrm{H}_{2} \mathrm{O}_{2}$-induced apoptosis (Chen et al. 2015).

However, not all miRNAs with antiapoptotic effects will have an acute cardioprotective effect after IRI in vivo. We found that miR-222 is necessary and sufficient to reduce cardiomyocyte apoptosis in vitro, and transgenic miR-222 overexpression in vivo reduces cardiomyocyte apoptosis late after IRI (Liu et al. 2015). However, the initial infarct size measured at 24 hours was not altered by miR-222 overexpression. Cardiac-specific overexpression of miR-222 in mice did improve cardiac function, in association with increased markers of cardiomyocyte proliferation as well as reduced cardiomyocyte apoptosis and fibrosis "late" after IRI. Thus, although miR-222 does not appear to contribute to the acute cardioprotective effects of exercise, it does substantially reduce late adverse remodeling after ischemic injury. Presumably the same may be true of other miRNA candidates with prosurvival effects in cardiomyocytes and thus the possible contribution of miRNAs to the acute cardioprotective effects of exercise remains unclear.

\section{Cardiac Fibrosis}

Cardiac fibrosis occurs in many cardiac pathologies and is not generally associated with exercise. Cardiac fibrosis can have important clinical implications by increasing myocardial stiffness and diastolic dysfunction, as well as contributing to arrhythmia by interfering with homogeneous electrical propagation. Exercise appears to attenuate cardiac fibrosis (Wright et al. 2014; Ma et al. 2015) and multiple miRNAs may contribute in this context. van Rooij et al. (2006) showed that the miR-29 family (miR$29 \mathrm{a}, \mathrm{b}, \mathrm{c})$ can act as negative regulators of car- 
X. Liu et al.

diac fibrosis after MI. In related studies, Soci et al. (2011) showed that increased miR-29a and $\mathrm{c}$ correlates with decreased COL1A1 and COL3A1 in the exercised heart, suggesting that miR-29 may regulate fibrosis in both physiological and pathological states. We also found that miR-29c was increased in two distinct exercise models (Liu et al. 2015). Consistently, Souza and Melo and colleagues found that the decrease in miR-29 ( $\mathrm{a}$ and c) seen in failing rat hearts was attenuated by aerobic exercise training, resulting in decreased collagen expression (Melo et al. 2014; Souza et al. 2015) and suggesting that exercise-induced miR-29 could help mitigate fibrosis and thereby improve ventricular function. We found that overexpression of miR-222, which is also upregulated in two distinct exercise models, inhibited cardiac fibrosis by three- to fourfold after IRI (Liu et al. 2015). Similarly, multiple other miRNAs that have been reported to regulate cardiac fibrosis in disease states are altered by exercise (Fig. 2B), raising the possibility that they contribute to the antifibrotic effects of exercise.

\section{Angiogenesis}

An increase in neovascular formation or angiogenesis is associated with endurance exercise. Using endothelial-cell-specific deletion of $\mathrm{Di}$ cer, Suarez et al. (2008) showed that endothelial miRNAs are essential for postnatal angiogenesis in many contexts. Although a Dicer role in exercise-induced cardiac angiogenesis was not directly examined, it seems likely. Endothelial miR-126 was shown to be involved in endothelial homeostasis and angiogenesis (Fish et al. 2008; Wang et al. 2008). Intriguingly, da Silva et al. (2012) reported that swim training increased expression of cardiac miR-126, which was positively correlated with the increase in LV capillary-fiber ratio. Taken together, these results suggest that exercise-induced miR-126 may contribute to angiogenesis in the heart. Conversely, exercise decreased expression of miR-26b (Martinelli et al. 2014), which has well-documented antiangiogenic effects (Icli et al. 2013).

\section{SUMMARY AND CONCLUSION}

Growing evidence suggests that both circulating and cardiac miRNAs are dynamically regulated by exercise in animal models and humans. Although the functional effects of these miRNAs have been examined, several have documented roles in mediating the cardiac phenotypes associated with exercise. In other cases, functional contributions have been plausibly inferred from demonstrated effects in other settings. It appears that many miRNAs that are functionally important in the heart's response to exercise also mitigate its response to pathological stress and disease. These preliminary studies provide cause for optimism that ongoing investigations of these pathways may not only provide novel biological insights but could also lay a foundation for new therapeutic approaches to preventing or treating a range of cardiovascular diseases.

\section{ACKNOWLEDGMENTS}

This work is supported by grants from the National Institutes of Health (NIH) (A.R. [R01HL110733, R01HL122987], X.L. [T32HL073734], and C.P. [T32GM007226]) and the American Heart Association (Collaborative Research Award and a Strategically Focused Research Network on Heart Failure). A.R. is a principal faculty member of the Harvard Stem Cell Institute.

\section{REFERENCES}

Akat KM, Moore-McGriff D, Morozov P, Brown M, Gogakos T, Correa Da Rosa J, Mihailovic A, Sauer M, Ji R, Ramarathnam A, et al. 2014. Comparative RNA-sequencing analysis of myocardial and circulating small RNAs in human heart failure and their utility as biomarkers. Proc Natl Acad Sci 111: 11151-11156.

Ali SR, Hippenmeyer S, Saadat LV, Luo L, Weissman IL, Ardehali R. 2014. Existing cardiomyocytes generate cardiomyocytes at a low rate after birth in mice. Proc Natl Acad Sci 111: 8850-8855.

Andrews Portes L, Magalhaes Saraiva R, Alberta Dos Santos A, Tucci PJ. 2009. Swimming training attenuates remodeling, contractile dysfunction and congestive heart failure in rats with moderate and large myocardial infarctions. Clin Exp Pharmacol Physiol 36: 394-399.

Aoi W, Ichikawa H, Mune K, Tanimura Y, Mizushima K, Naito Y, Yoshikawa T. 2013. Muscle-enriched microRNA 
miR-486 decreases in circulation in response to exercise in young men. Front Physiol 4: 80.

Arany Z, Novikov M, Chin S, Ma Y, Rosenzweig A, Spiegelman BM. 2006. Transverse aortic constriction leads to accelerated heart failure in mice lacking PPAR- $\gamma$ coactivator 1 $\alpha$. Proc Natl Acad Sci 103: 10086-10091.

Arany Z, Foo SY, Ma Y, Ruas JL, Bommi-Reddy A, Girnun G, Cooper M, Laznik D, Chinsomboon J, Rangwala SM, et al. 2008. HIF-independent regulation of VEGF and angiogenesis by the transcriptional coactivator PGC- $1 \alpha$. Nature 451: 1008-1012.

Arroyo JD, Chevillet JR, Kroh EM, Ruf IK, Pritchard CC, Gibson DF, Mitchell PS, Bennett CF, Pogosova-Agadjanyan EL, Stirewalt DL, et al. 2011. Argonaute2 complexes carry a population of circulating microRNAs independent of vesicles in human plasma. Proc Natl Acad Sci 108: $5003-5008$.

Aurora AB, Mahmoud AI, Luo X, Johnson BA, van Rooij E, Matsuzaki S, Humphries KM, Hill JA, Bassel-Duby R, Sadek HA, et al. 2012. MicroRNA-214 protects the mouse heart from ischemic injury by controlling $\mathrm{Ca}^{2+}$ overload and cell death. J Clin Invest 122: 1222-1232.

Baggish AL, Wang F, Weiner RB, Elinoff JM, Tournoux F, Boland A, Picard MH, Hutter AM Jr, Wood MJ. 2008. Training-specific changes in cardiac structure and function: A prospective and longitudinal assessment of competitive athletes. J Appl Physiol (1985) 104: 1121-1128.

Baggish AL, Hale A, Weiner RB, Lewis GD, Systrom D, Wang F, Wang TJ, Chan SY. 2011. Dynamic regulation of circulating microRNA during acute exhaustive exercise and sustained aerobic exercise training. J Physiol 589: $3983-$ 3994.

Bang C, Batkai S, Dangwal S, Gupta SK, Foinquinos A, Holzmann A, Just A, Remke J, Zimmer K, Zeug A, et al. 2014. Cardiac fibroblast-derived microRNA passenger strand-enriched exosomes mediate cardiomyocyte hypertrophy. J Clin Invest 124: 2136-2146.

Barboza CA, Rocha LY, Mostarda CT, Figueroa D, Caperuto EC, De Angelis K, Irigoyen MC, Rodrigues B. 2013. Ventricular and autonomic benefits of exercise training persist after detraining in infarcted rats. Eur J Appl Physiol 113: 1137-1146.

Bartel DP. 2004. MicroRNAs: Genomics, biogenesis, mechanism, and function. Cell 116: 281-297.

Bergmann O, Bhardwaj RD, Bernard S, Zdunek S, BarnabeHeider F, Walsh S, Zupicich J, Alkass K, Buchholz BA, Druid H, et al. 2009. Evidence for cardiomyocyte renewal in humans. Science 324: 98-102.

Bersell K, Arab S, Haring B, Kuhn B. 2009. Neuregulin1/ ErbB4 signaling induces cardiomyocyte proliferation and repair of heart injury. Cell 138: 257-270.

Bezzerides VJ, Platt C, Lerchenmuller C, Paruchuri K, Oh NL, Xiao C, Cao Y, Mann N, Spiegelman BM, Rosenzweig A. 2016. CITED4 induces physiologic hypertrophy and promotes functional recovery after ischemic injury. JCI Insight 1: e85904.

Bhupathiraju SN, Hu FB. 2016. Epidemiology of obesity and diabetes and their cardiovascular complications. Circ Res 118: $1723-1735$.

Bostrom P, Mann N, Wu J, Quintero PA, Plovie ER, kova DP, Gupta RK, Xiao C, MacRae CA, Rosenzweig A, et al. 2010. C/EBP $\beta$ controls exercise-induced cardiac growth and protects against pathological cardiac remodeling. Cell 143: 1072-1083.

Cai MX, Shi XC, Chen T, Tan ZN, Lin QQ, Du SJ, Tian ZJ. 2016. Exercise training activates neuregulin 1/ErbB signaling and promotes cardiac repair in a rat myocardial infarction model. Life Sci 149: 1-9.

Calvert JW, Condit ME, Aragon JP, Nicholson CK, Moody BF, Hood RL, Sindler AL, Gundewar S, Seals DR, Barouch LA, et al. 2011. Exercise protects against myocardial ischemia-reperfusion injury via stimulation of $\beta_{3}$-adrenergic receptors and increased nitric oxide signaling: Role of nitrite and nitrosothiols. Circ Res 108: 1448-1458.

Care A, Catalucci D, Felicetti F, Bonci D, Addario A, Gallo P, Bang ML, Segnalini P, Gu Y, Dalton ND, et al. 2007. MicroRNA-133 controls cardiac hypertrophy. Nat Med 13: $613-618$.

Cha MJ, Jang JK, Ham O, Song BW, Lee SY, Lee CY, Park JH, Lee J, Seo HH, Choi E, et al. 2013. MicroRNA-145 suppresses ROS-induced $\mathrm{Ca}^{2+}$ overload of cardiomyocytes by targeting CaMKIII. Biochem Biophys Res Commun 435: 720-726.

Chen J, Huang ZP, Seok HY, Ding J, Kataoka M, Zhang Z, Hu $\mathrm{X}$, Wang $\mathrm{G}$, Lin Z, Wang S, et al. 2013. mir-17-92 cluster is required for and sufficient to induce cardiomyocyte proliferation in postnatal and adult hearts. Circ Res 112: 1557-1566.

Chen A, Li G, Chen L, Guo J, Liu Y. 2015. Downregulation of microRNA-100 protects $\mathrm{H}_{2} \mathrm{O}_{2}$-induced apoptosis in neonatal cardiomyocytes. Int J Exp Pathol 8: 5491-5496.

Cheng Y, Liu X, Zhang S, Lin Y, Yang J, Zhang C. 2009. MicroRNA-21 protects against the $\mathrm{H}_{2} \mathrm{O}_{2}$-induced injury on cardiac myocytes via its target gene PDCD4. J Mol Cell Cardiol 47: 5-14.

Chicco AJ, Hydock DS, Schneider CM, Hayward R. 2006. Low-intensity exercise training during doxorubicin treatment protects against cardiotoxicity. JAppl Physiol (1985) 100: $519-527$.

Christensen K, Doblhammer G, Rau R, Vaupel JW. 2009. Ageing populations: The challenges ahead. Lancet 374: 1196-1208.

Da Costa Martins PA, De Windt LJ. 2012. MicroRNAs in control of cardiac hypertrophy. Cardiovasc Res 93: $563-$ 572.

da Silva ND Jr, Fernandes T, Soci UP, Monteiro AW, Phillips MI, EM DEO. 2012. Swimming training in rats increases cardiac microRNA-126 expression and angiogenesis. Med Sci Sports Exerc 44: 1453-1462.

DeBosch B, Treskov I, Lupu TS, Weinheimer C, Kovacs A, Courtois M, Muslin AJ. 2006. Akt1 is required for physiological cardiac growth. Circulation 113: 2097-2104.

DeMaria AN, Neumann A, Lee G, Fowler W, Mason DT. 1978. Alterations in ventricular mass and performance induced by exercise training in man evaluated by echocardiography. Circulation 57: 237-244.

Diffee GM, Chung E. 2003. Altered single cell force-velocity and power properties in exercise-trained rat myocardium. J Appl Physiol (1985) 94: 1941-1948.

Dirkx E, Gladka MM, Philippen LE, Armand AS, Kinet V, Leptidis S, El Azzouzi H, Salic K, Bourajjaj M, da Silva GJ, et al. 2013. Nfat and miR-25 cooperate to reactivate the 
X. Liu et al.

transcription factor Hand2 in heart failure. Nat Cell Biol 15: $1282-1293$.

Dong S, Cheng Y, Yang J, Li J, Liu X, Wang X, Wang D, Krall TJ, Delphin ES, Zhang C. 2009. MicroRNA expression signature and the role of microRNA-21 in the early phase of acute myocardial infarction. J Biol Chem 284: 2951429525.

Duncker DJ, Bache RJ. 2008. Regulation of coronary blood flow during exercise. Physiol Rev 88: 1009-1086.

Eijsvogels TM, George KP, Thompson PD. 2016. Cardiovascular benefits and risks across the physical activity continuum. Curr Opin Cardiol 31: 566-571.

Ellison GM, Waring CD, Vicinanza C, Torella D. 2012. Physiological cardiac remodelling in response to endurance exercise training: Cellular and molecular mechanisms. Heart 98: 5-10.

Elmén J, Lindow M, Schütz S, Lawrence M, Petri A, Obad S, Lindholm M, Hedtjärn M, Hansen HF, Berger U, et al. 2008. LNA-mediated microRNA silencing in non-human primates. Nature 452: 896-899.

Eulalio A, Mano M, Dal Ferro M, Zentilin L, Sinagra G, Zacchigna S, Giacca M. 2012. Functional screening identifies miRNAs inducing cardiac regeneration. Nature 492: $376-381$.

Fang SJ, Wu XS, Han ZH, Zhang XX, Wang CM, Li XY, Lu LQ, Zhang JL. 2010. Neuregulin-1 preconditioning protects the heart against ischemia/reperfusion injury through a PI3K/Akt-dependent mechanism. Chin Med $J$ (Engl) 123: 3597-3604.

Fernandes T, Hashimoto NY, Magalhaes FC, Fernandes FB, Casarini DE, Carmona AK, Krieger JE, Phillips MI, Oliveira EM. 2011. Aerobic exercise training-induced left ventricular hypertrophy involves regulatory MicroRNAs, decreased angiotensin-converting enzyme-angiotensin II, and synergistic regulation of angiotensin-converting enzyme 2-angiotensin (1-7). Hypertension 58: 182-189.

Ferrara N, Rinaldi B, Corbi G, Conti V, Stiuso P, Boccuti S, Rengo G, Rossi F, Filippelli A. 2008. Exercise training promotes SIRT1 activity in aged rats. Rejuvenation Res 11: $139-150$.

Fish JE, Santoro MM, Morton SU, Yu S, Yeh RF, Wythe JD, Ivey KN, Bruneau BG, Stainier DY, Srivastava D. 2008. miR-126 regulates angiogenic signaling and vascular integrity. Dev Cell 15: 272-284.

Ford ES, Ajani UA, Croft JB, Critchley JA, Labarthe DR, Kottke TE, Giles WH, Capewell S. 2007. Explaining the decrease in U.S. deaths from coronary disease, 19802000. N Engl J Med 356: 2388-2398.

Frystyk J. 2010. Exercise and the growth hormone-insulinlike growth factor axis. Med Sci Sports Exerc 42: 58-66.

Galimberti D, Villa C, Fenoglio C, Serpente M, Ghezzi L, Cioffi SM, Arighi A, Fumagalli G, Scarpini E. 2014. Circulating miRNAs as potential biomarkers in Alzheimer's disease. J Alzheimers Dis 42: 1261-1267.

Gomes CP, Oliveira-Jr GP, Madrid B, Almeida JA, Franco OL, Pereira RW. 2014. Circulating miR-1, miR-133a, and miR-206 levels are increased after a half-marathon run. Biomarkers 19: 585-589.

Hambrecht R, Wolf A, Gielen S, Linke A, Hofer J, Erbs S, Schoene N, Schuler G. 2000. Effect of exercise on coro- nary endothelial function in patients with coronary artery disease. N Engl J Med 342: 454-460.

Hergenreider E, Heydt S, Treguer K, Boettger T, Horrevoets AJ, Zeiher AM, Scheffer MP, Frangakis AS, Yin X, Mayr M, et al. 2012. Atheroprotective communication between endothelial cells and smooth muscle cells through miRNAs. Nat Cell Biol 14: 249-256.

Hsu CP, Zhai P, Yamamoto T, Maejima Y, Matsushima S, Hariharan N, Shao D, Takagi H, Oka S, Sadoshima J. 2010. Silent information regulator 1 protects the heart from ischemia/reperfusion. Circulation 122: 2170-2182.

Icli B, Wara AK, Moslehi J, Sun X, Plovie E, Cahill M, Marchini JF, Schissler A, Padera RF, Shi J, et al. 2013. MicroRNA26a regulates pathological and physiological angiogenesis by targeting BMP/SMAD1 signaling. Circ Res 113: 1231-1241.

Janssen HL, Reesink HW, Lawitz EJ, Zeuzem S, RodriguezTorres M, Patel K, van der Meer AJ, Patick AK, Chen A, Zhou Y, et al. 2013. Treatment of HCV infection by targeting microRNA. N Engl J Med 368: 1685-1694.

Kemi OJ, Wisloff U. 2010. Mechanisms of exercise-induced improvements in the contractile apparatus of the mammalian myocardium. Acta Physiol 199: 425-439.

Kemi OJ, Ellingsen O, Ceci M, Grimaldi S, Smith GL, Condorelli G, Wisloff U. 2007a. Aerobic interval training enhances cardiomyocyte contractility and $\mathrm{Ca}^{2+}$ cycling by phosphorylation of CaMKII and Thr-17 of phospholamban. J Mol Cell Cardiol 43: 354-361.

Kemi OJ, Hoydal MA, Haram PM, Garnier A, Fortin D, Ventura-Clapier R, Ellingsen O. 2007b. Exercise training restores aerobic capacity and energy transfer systems in heart failure treated with losartan. Cardiovasc Res 76: $91-$ 99.

Kemi OJ, Ceci M, Wisloff U, Grimaldi S, Gallo P, Smith GL, Condorelli G, Ellingsen O. 2008. Activation or inactivation of cardiac Akt/mTOR signaling diverges physiological from pathological hypertrophy. J Cell Physiol 214: $316-321$.

Kemi OJ, Hoydal MA, Macquaide N, Haram PM, Koch LG, Britton SL, Ellingsen O, Smith GL, Wisloff U. 2011. The effect of exercise training on transverse tubules in normal, remodeled, and reverse remodeled hearts. J Cell Physiol 226: $2235-2243$.

Kim J, Wende AR, Sena S, Theobald HA, Soto J, Sloan C, Wayment BE, Litwin SE, Holzenberger M, LeRoith D, et al. 2008. Insulin-like growth factor I receptor signaling is required for exercise-induced cardiac hypertrophy. $\mathrm{Mol}$ Endocrinol 22: 2531-2543.

La Gerche A, Prior DL. 2007. Exercise-Is it possible to have too much of a good thing? Heart Lung Circ 16: S102S104.

Lai CH, Ho TJ, Kuo WW, Day CH, Pai PY, Chung LC, Liao PH, Lin FH, Wu ET, Huang CY. 2014. Exercise training enhanced SIRT1 longevity signaling replaces the IGF1 survival pathway to attenuate aging-induced rat heart apoptosis. Age (Dordr) 36: 9706.

Lennon SL, Quindry J, Hamilton KL, French J, Staib J, Mehta JL, Powers SK. 2004. Loss of exercise-induced cardioprotection after cessation of exercise. J Appl Physiol (1985) 96: 1299-1305.

Leosco D, Rengo G, Iaccarino G, Golino L, Marchese M, Fortunato F, Zincarelli C, Sanzari E, Ciccarelli M, Galasso 
G, et al. 2008. Exercise promotes angiogenesis and improves beta-adrenergic receptor signalling in the postischaemic failing rat heart. Cardiovasc Res 78: 385-394.

Li Z, Liu L, Hou N, Song Y, An X, Zhang Y, Yang X, Wang J. 2016. miR-199-sponge transgenic mice develop physiological cardiac hypertrophy. Cardiovasc Res 110: 258267.

Lin RC, Weeks KL, Gao XM, Williams RB, Bernardo BC, Kiriazis H, Matthews VB, Woodcock EA, Bouwman RD, Mollica JP, et al. 2010. PI3K $(\mathrm{p} 110 \alpha)$ protects against myocardial infarction-induced heart failure: Identification of PI3K-regulated miRNA and mRNA. Arterioscler Thromb Vasc Biol 30: 724-732.

Liu X, Xiao J, Zhu H, Wei X, Platt C, Damilano F, Xiao C, Bezzerides V, Bostrom P, Che L, et al. 2015. miR-222 is necessary for exercise-induced cardiac growth and protects against pathological cardiac remodeling. Cell Metab 21: 584-595.

Ma Z, Qi J, Meng S, Wen B, Zhang J. 2013. Swimming exercise training-induced left ventricular hypertrophy involves microRNAs and synergistic regulation of the PI3K/AKT/mTOR signaling pathway. Eur J Appl Physiol 113: $2473-2486$.

Ma X, Fu Y, Xiao H, Song Y, Chen R, Shen J, An X, Shen Q, Li Z, Zhang Y. 2015. Cardiac fibrosis alleviated by exercise training is AMPK-dependent. PLoS ONE 10: e129971.

Martinelli NC, Cohen CR, Santos KG, Castro MA, Biolo A Frick L, Silvello D, Lopes A, Schneider S, Andrades ME, et al. 2014. An analysis of the global expression of microRNAs in an experimental model of physiological left ventricular hypertrophy. PLoS ONE 9: e93271.

Matsui T, Li L, MonteF d, Fukui Y, Franke TF, Hajjar RJ, Rosenzweig A. 1999. Adenoviral gene transfer of activated phosphatidylinositol $3^{\prime}$-kinase and Akt inhibits apoptosis of hypoxic cardiomyocytes in vitro. Circulation 100: 2373-2379.

Matsui T, Tao J, del Monte F, Lee KH, Li L, Picard M, Force TL, Franke TF, Hajjar RJ, Rosenzweig A. 2001. Akt activation preserves cardiac function and prevents injury after transient cardiac ischemia in vivo. Circulation 104: $330-335$.

Matsui T, Nagoshi T, Rosenzweig A. 2003. Akt and PI3-kinase signaling in cardiomyocyte hypertrophy and survival. Cell Cycle 2: 220-223.

McDiarmid AK, Swoboda PP, Erhayiem B, Lancaster RE, Lyall GK, Broadbent DA, Dobson LE, Musa TA, Ripley DP, Garg P, et al. 2016. Athletic cardiac adaptation in males is a consequence of elevated myocyte mass. Circ Cardiovasc Imaging 9: e003579.

McMullen JR, Shioi T, Zhang L, Tarnavski O, Sherwood MC, Kang PM, Izumo S. 2003. Phosphoinositide 3-kinase $(\mathrm{p} 110 \alpha)$ plays a critical role for the induction of physiological, but not pathological, cardiac hypertrophy. Proc Natl Acad Sci 100: 12355-12360.

McMullen JR, Shioi T, Huang WY, Zhang L, Tarnavski O, Bisping E, Schinke M, Kong S, Sherwood MC, Brown J, et al. 2004. The insulin-like growth factor 1 receptor induces physiological heart growth via the phosphoinositide 3 kinase $(\mathrm{p} 110 \alpha)$ pathway. J Biol Chem 279: 4782-4793.

Melo SF, Fernandes T, Barauna VG, Matos KC, Santos AA, Tucci PJ, Oliveira EM. 2014. Expression of microRNA-29 and collagen in cardiac muscle after swimming training in myocardial-infarcted rats. Cell Physiol Biochem 33: 657-669.

Melo SF, Barauna VG, Junior MA, Bozi LH, Drummond LR, Natali AJ, de Oliveira EM. 2015a. Resistance training regulates cardiac function through modulation of miRNA214. Int J Mol Sci 16: 6855-6867.

Melo SF, Barauna VG, Neves VJ, Fernandes T, Lara Lda S, Mazzotti DR, Oliveira EM. 2015b. Exercise training restores the cardiac microRNA-1 and -214 levels regulating $\mathrm{Ca}^{2+}$ handling after myocardial infarction. BMC Cardiovasc Disord 15: 166.

Mitchell PS, Parkin RK, Kroh EM, Fritz BR, Wyman SK, Pogosova-Agadjanyan EL, Peterson A, Noteboom J, O'Briant KC, Allen A, et al. 2008. Circulating microRNAs as stable blood-based markers for cancer detection. Proc Natl Acad Sci 105: 10513-10518.

Molkentin JD, Lu JR, Antos CL, Markham B, Richardson J, Robbins J, Grant SR, Olson EN. 1998. A calcineurin-dependent transcriptional pathway for cardiac hypertrophy. Cell 93: 215-228.

Mooren FC, Viereck J, Kruger K, Thum T. 2014. Circulating microRNAs as potential biomarkers of aerobic exercise capacity. Am J Physiol Heart Circ Physiol 306: H557H563.

Naci H, Ioannidis JP. 2013. Comparative effectiveness of exercise and drug interventions on mortality outcomes: Metaepidemiological study. BMJ 347: f5577.

Neri Serneri GG, Boddi M, Modesti PA, Cecioni I, Coppo M, Padeletti L, Michelucci A, Colella A, Galanti G. 2001 Increased cardiac sympathetic activity and insulin-like growth factor-I formation are associated with physiological hypertrophy in athletes. Circ Res 89: 977-982.

O'Connor CM, Whellan DJ, Lee KL, Keteyian SJ, Cooper LS, Ellis SJ, Leifer ES, Kraus WE, Kitzman DW, Blumenthal JA, et al. 2009. Efficacy and safety of exercise training in patients with chronic heart failure: HF-ACTION randomized controlled trial. JAMA 301: 1439-1450.

Odiete O, Hill MF, Sawyer DB. 2012. Neuregulin in cardiovascular development and disease. Circ Res 111: $1376-$ 1385.

O’Keefe JH, Patil HR, Lavie CJ, Magalski A, Vogel RA, McCullough PA. 2012. Potential adverse cardiovascular effects from excessive endurance exercise. Mayo Clin Proc 87: 587-595.

Pillai VB, Sundaresan NR, Jeevanandam V, Gupta MP. 2010. Mitochondrial SIRT3 and heart disease. Cardiovasc Res 88: $250-256$.

Pons S, Martin V, Portal L, Zini R, Morin D, Berdeaux A, Ghaleh B. 2013. Regular treadmill exercise restores cardioprotective signaling pathways in obese mice independently from improvement in associated co-morbidities. J Mol Cell Cardiol 54: 82-89.

Powers SK, Lennon SL, Quindry J, Mehta JL. 2002. Exercise and cardioprotection. Curr Opin Cardiol 17: 495-502.

Powers SK, Quindry JC, Kavazis AN. 2008. Exercise-induced cardioprotection against myocardial ischemia-reperfusion injury. Free Radic Biol Med 44: 193-201.

Qin D, Wang X, Li Y, Yang L, Wang R, Peng J, Essandoh K, Mu X, Peng T, Han Q, et al. 2016. MicroRNA-223-5p and $-3 p$ cooperatively suppress necroptosis in ischemic/reperfused hearts. J Biol Chem 291: 20247-20259. 
X. Liu et al.

Ramasamy S, Velmurugan G, Shanmugha Rajan K, Ramprasath T, Kalpana K. 2015. MiRNAs with apoptosis regulating potential are differentially expressed in chronic exercise-induced physiologically hypertrophied hearts. PLOS ONE 10: e0121401.

Reiss K, Cheng W, Ferber A, Kajstura J, Li P, Li B, Olivetti G, Homcy CJ, Baserga R, Anversa P. 1996. Overexpression of insulin-like growth factor- 1 in the heart is coupled with myocyte proliferation in transgenic mice. Proc Natl Acad Sci 93: 8630-8635.

Roh J, Rhee J, Chaudhari V, Rosenzweig A. 2016. The role of exercise in cardiac aging: From physiology to molecular mechanisms. Circ Res 118: 279-295.

Sawada S, Kon M, Wada S, Ushida T, Suzuki K, Akimoto T. 2013. Profiling of circulating microRNAs after a bout of acute resistance exercise in humans. PLoS ONE 8: e70823.

Senyo SE, Steinhauser ML, Pizzimenti CL, Yang VK, Cai L, Wang M, Wu TD, Guerquin-Kern JL, Lechene CP, Lee RT. 2013. Mammalian heart renewal by pre-existing cardiomyocytes. Nature 493: 433-436.

Shioi T, Kang PM, Douglas PS, Hampe J, Yballe CM, Lawitts J, Cantley LC, Izumo S. 2000. The conserved phosphoinositide 3-kinase pathway determines heart size in mice. EMBO J 19: 2537-2548.

Small EM, Olson EN. 2011. Pervasive roles of microRNAs in cardiovascular biology. Nature 469: 336-342.

Smart N, Bollini S, Dube KN, Vieira JM, Zhou B, Davidson S, Yellon D, Riegler J, Price AN, Lythgoe MF, et al. 2011. De novo cardiomyocytes from within the activated adult heart after injury. Nature 474: 640-644.

Soci UP, Fernandes T, Hashimoto NY, Mota GF, Amadeu MA, Rosa KT, Irigoyen MC, Phillips MI, Oliveira EM. 2011. MicroRNAs 29 are involved in the improvement of ventricular compliance promoted by aerobic exercise training in rats. Physiol Genomics 43: 665-673.

Song DW, Ryu JY, Kim JO, Kwon EJ, Kim do H. 2014. The miR-19a/b family positively regulates cardiomyocyte hypertrophy by targeting atrogin- 1 and MuRF-1. Biochem J 457: $151-162$.

Souza RW, Fernandez GJ, Cunha JP, Piedade WP, Soares LC, Souza PA, de Campos DH, Okoshi K, Cicogna AC, DalPai-Silva M, et al. 2015. Regulation of cardiac microRNAs induced by aerobic exercise training during heart failure. Am J Physiol Heart Circ Physiol 309: H1629H1641.

Stolen TO, Hoydal MA, Kemi OJ, Catalucci D, Ceci M, Aasum E, Larsen T, Rolim N, Condorelli G, Smith GL, et al. 2009. Interval training normalizes cardiomyocyte function, diastolic $\mathrm{Ca}^{2+}$ control, and SR $\mathrm{Ca}^{2+}$ release synchronicity in a mouse model of diabetic cardiomyopathy. Circ Res 105: 527-536.

Suarez Y, Fernandez-Hernando C, Yu J, Gerber SA, Harrison KD, Pober JS, Iruela-Arispe ML, Merkenschlager M, Sessa WC. 2008. Dicer-dependent endothelial microRNAs are necessary for postnatal angiogenesis. Proc Natl Acad Sci 105: 14082-14087.

Sundaresan NR, Gupta M, Kim G, Rajamohan SB, Isbatan A, Gupta MP. 2009. Sirt3 blocks the cardiac hypertrophic response by augmenting Foxo3a-dependent antioxidant defense mechanisms in mice. J Clin Invest 119: 2758 2771.
Turchinovich A, Weiz L, Langheinz A, Burwinkel B. 2011. Characterization of extracellular circulating microRNA. Nucleic Acids Res 39: 7223-7233.

Ucar A, Gupta SK, Fiedler J, Erikci E, Kardasinski M, Batkai S, Dangwal S, Kumarswamy R, Bang C, Holzmann A, et al. 2012. The miRNA-212/132 family regulates both cardiac hypertrophy and cardiomyocyte autophagy. Nat Commun 3: 1078.

Uhlemann M, Mobius-Winkler S, Fikenzer S, Adam J, Redlich M, Mohlenkamp S, Hilberg T, Schuler GC, Adams V. 2014. Circulating microRNA-126 increases after different forms of endurance exercise in healthy adults. Eur J Prev Cardiol 21: 484-491.

Utomi V, Oxborough D, Whyte GP, Somauroo J, Sharma S, Shave R, Atkinson G, George K. 2013. Systematic review and meta-analysis of training mode, imaging modality and body size influences on the morphology and function of the male athlete's heart. Heart 99: 1727-1733.

Valadi H, Ekstrom K, Bossios A, Sjostrand M, Lee JJ, Lotvall JO. 2007. Exosome-mediated transfer of mRNAs and microRNAs is a novel mechanism of genetic exchange between cells. Nat Cell Biol 9: 654-659.

van Praag H, Kempermann G, Gage FH. 1999. Running increases cell proliferation and neurogenesis in the adult mouse dentate gyrus. Nat Neurosci 2: 266-270.

van Praag H, Shubert T, Zhao C, Gage FH. 2005. Exercise enhances learning and hippocampal neurogenesis in aged mice. J Neurosci 25: 8680-8685.

van Rooij E, Sutherland LB, Liu N, Williams AH, McAnally J, Gerard RD, Richardson JA, Olson EN. 2006. A signature pattern of stress-responsive microRNAs that can evoke cardiac hypertrophy and heart failure. Proc Natl Acad Sci 103: $18255-18260$.

Vettor R, Valerio A, Ragni M, Trevellin E, Granzotto M, Olivieri M, Tedesco L, Ruocco C, Fossati A, Fabris R, et al. 2014. Exercise training boosts eNOS-dependent mitochondrial biogenesis in mouse heart: Role in adaptation of glucose metabolism. Am J Physiol Endocrinol Metab 306: E519-E528.

Wang J, Yang X. 2012. The function of miRNA in cardiac hypertrophy. Cell Mol Life Sci 69: 3561-3570.

Wang S, Aurora AB, Johnson BA, Qi X, McAnally J, Hill JA, Richardson JA, Bassel-Duby R, Olson EN. 2008. The endothelial-specific microRNA miR-126 governs vascular integrity and angiogenesis. Dev Cell 15: $261-$ 271.

Wang K, Zhang S, Weber J, Baxter D, Galas DJ. 2010. Export of microRNAs and microRNA-protective protein by mammalian cells. Nucleic Acids Res 38: 7248-7259.

Wang JX, Jiao JQ, Li Q, Long B, Wang K, Liu JP, Li YR, Li PF 2011. miR-499 regulates mitochondrial dynamics by targeting calcineurin and dynamin-related protein-1. Nat Med 17: 71-78.

Wang X, Guo B, Li Q, Peng J, Yang Z, Wang A, Li D, Hou Z, Lv K, Kan G, et al. 2013. miR-214 targets ATF4 to inhibit bone formation. Nat Med 19: 93-100.

Wardle SL, Bailey ME, Kilikevicius A, Malkova D, Wilson RH, Venckunas T, Moran CN. 2015. Plasma microRNA levels differ between endurance and strength athletes. PLoS ONE 10: e0122107. 
Waring CD, Vicinanza C, Papalamprou A, Smith AJ, Purushothaman S, Goldspink DF, Nadal-Ginard B, Torella D, Ellison GM. 2014. The adult heart responds to increased workload with physiologic hypertrophy, cardiac stem cell activation, and new myocyte formation. Eur Heart $J$ 35: 2722-2731.

Wasfy MM, Weiner RB, Wang F, Berkstresser B, Lewis GD, DeLuca JR, Hutter AM, Picard MH, Baggish AL. 2015. Endurance exercise-induced cardiac remodeling: Not all sports are created equal. JAm Soc Echocardiogr 28: 14341440.

Weeks KL, Gao X, Du XJ, Boey EJ, Matsumoto A, Bernardo BC, Kiriazis H, Cemerlang N, Tan JW, Tham YK, et al. 2012. Phosphoinositide 3-kinase $\mathrm{p} 110 \alpha$ is a master regulator of exercise-induced cardioprotection and PI3K gene therapy rescues cardiac dysfunction. Circ Heart Fail 5: 523-534.

Wei X, Liu X, Rosenzweig A. 2014. What do we know about the cardiac benefits of exercise? Trends Cardiovasc Med 25: $529-536$.

White FC, Bloor CM, McKirnan MD, Carroll SM. 1998. Exercise training in swine promotes growth of arteriolar bed and capillary angiogenesis in heart. J Appl Physiol (1985) 85: 1160-1168.

Wilson MG, Ellison GM, Cable NT. 2016. Basic science behind the cardiovascular benefits of exercise. Br J Sports Med 50: 93-99.

Wisloff U, Loennechen JP, Falck G, Beisvag V, Currie S Smith G, Ellingsen O. 2001. Increased contractility and calcium sensitivity in cardiac myocytes isolated from endurance trained rats. Cardiovasc Res 50: 495-508.

Wisloff U, Loennechen JP, Currie S, Smith GL, Ellingsen O. 2002. Aerobic exercise reduces cardiomyocyte hypertrophy and increases contractility, $\mathrm{Ca}^{2+}$ sensitivity and
SERCA-2 in rat after myocardial infarction. Cardiovasc Res 54: $162-174$.

Wright KJ, Thomas MM, Betik AC, Belke D, Hepple RT. 2014. Exercise training initiated in late middle age attenuates cardiac fibrosis and advanced glycation end-product accumulation in senescent rats. Exp Gerontol 50: 918

Xiao J, Xu T, Li J, Lv D, Chen P, Zhou Q, Xu J. 2014. Exerciseinduced physiological hypertrophy initiates activation of cardiac progenitor cells. Int J Clin Exp Pathol 7: 663-669.

Yan T, Cui K, Huang X, Ding S, Zheng Y, Luo Q, Liu X, Zou L. 2014. Assessment of therapeutic efficacy of miR-126 with contrast-enhanced ultrasound in preeclampsia rats. Placenta 35: 23-29.

Yang T, Zhang GF, Chen XF, Gu HH, Fu SZ, Xu HF, Feng Q, Ni YM. 2013. MicroRNA-214 provokes cardiac hypertrophy via repression of EZH2. Biochem Biophys Res Commun 436: 578-584.

Zernecke A, Bidzhekov K, Noels H, Shagdarsuren E, Gan L, Denecke B, Hristov M, Koppel T, Jahantigh MN, Lutgens E, et al. 2009. Delivery of microRNA-126 by apoptotic bodies induces CXCL12-dependent vascular protection. Sci Signal 2: ra81.

Zhang QJ, McMillin SL, Tanner JM, Palionyte M, Abel ED, Symons JD. 2009. Endothelial nitric oxide synthase phosphorylation in treadmill-running mice: Role of vascular signalling kinases. J Physiol 587: 3911-3920.

Zhao YC. 2015. Effects of exercise training on myocardial mitochondrial miR-499-CaN-Drp-1 apoptotic pathway in mice. Zhongguo Ying Yong Sheng Li Xue Za Zhi 31: 259-263.

Zhao Y, Samal E, Srivastava D. 2005. Serum response factor regulates a muscle-specific microRNA that targets Hand2 during cardiogenesis. Nature 436: 214-220. 


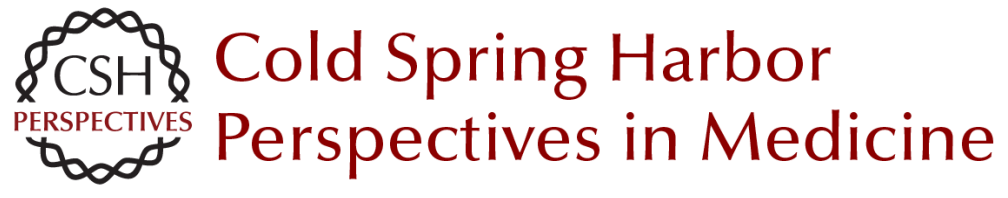

\section{The Role of MicroRNAs in the Cardiac Response to Exercise}

Xiaojun Liu, Colin Platt and Anthony Rosenzweig

Cold Spring Harb Perspect Med 2017; doi: 10.1101/cshperspect.a029850 originally published online April 7, 2017

\section{Subject Collection The Biology of Exercise}

Exosomes as Mediators of the Systemic

Adaptations to Endurance Exercise Adeel Safdar and Mark A. Tarnopolsky

Molecular Basis of Exercise-Induced Skeletal

Muscle Mitochondrial Biogenesis: Historical

Advances, Current Knowledge, and Future

Challenges

Christopher G.R. Perry and John A. Hawley

Exercise Metabolism: Fuels for the Fire Mark Hargreaves and Lawrence L. Spriet

Health Benefits of Exercise Gregory N. Ruegsegger and Frank W. Booth

Molecular Regulation of Exercise-Induced Muscle

Fiber Hypertrophy Marcas M. Bamman, Brandon M. Roberts and Gregory R. Adams

Physiological Redundancy and the Integrative Responses to Exercise Michael J. Joyner and Jerome A. Dempsey

On the Run for Hippocampal Plasticity C'iana Cooper, Hyo Youl Moon and Henriette van Praag

Molecular Basis for Exercise-Induced Fatigue: The Importance of Strictly Controlled Cellular $\mathrm{Ca}$

2+ Handling

Arthur J. Cheng, Nicolas Place and Håkan

Westerblad
Effects of Exercise and Aging on Skeletal Muscle Giovanna Distefano and Bret $H$. Goodpaster

Muscle-Adipose Tissue Cross Talk Kristin I. Stanford and Laurie J. Goodyear

Performance Fatigability: Mechanisms and Task Specificity Sandra K. Hunter

Adaptations to Endurance and Strength Training David C. Hughes, Stian Ellefsen and Keith Baar

The Bioenergetics of Exercise $P$. Darrell Neufer

Effects of Exercise on Vascular Function, Structure, and Health in Humans Daniel J. Green and Kurt J. Smith

Control of Muscle Metabolism by the Mediator Complex

Leonela Amoasii, Eric N. Olson and Rhonda Bassel-Duby

Theoretical and Biological Evaluation of the Link between Low Exercise Capacity and Disease Risk Lauren Gerard Koch and Steven L. Britton

For additional articles in this collection, see http://perspectivesinmedicine.cshlp.org/cgi/collection/ 